\title{
Identification of Africanized honey bees through wing morphometrics: two fast and efficient procedures*
}

\author{
Tiago Mauricio FrancoY ${ }^{1}$, Dieter WitTMANN ${ }^{2}$, Martin DraUschKE ${ }^{3}$, Stefan \\ MÜLleR $^{3}$, Volker SteINHAGE ${ }^{3}$, Marcela A. F. BEZERRA-LAURE ${ }^{1}$, David DE JonG ${ }^{1}$, \\ Lionel Segui GONÇALVES ${ }^{4}$ \\ ${ }^{1}$ Depto. de Genética, Faculdade de Medicina de Ribeirão Preto, USP, Ribeirão Preto, SP, Brazil \\ ${ }^{2}$ Institut für Nutzpflanzenwissenschaften und Ressourcenschutz, Universität Bonn, Bonn, Germany \\ ${ }^{3}$ Institut für Informatik III, Universität Bonn, Bonn, Germany \\ ${ }^{4}$ Depto. de Biologia, Faculdade de Filosofia, Ciências e Letras de Ribeirão Preto, USP, Ribeirão Preto, SP, Brazil
}

Received 28 December 2007 - Revised 10 March 2008 - Accepted 19 March 2008

\begin{abstract}
Currently available morphometric and genetic techniques that can accurately identify Africanized honey bees are both costly and time consuming. We tested two new morphometric techniques (ABIS - Automatic Bee Identification System and geometric morphometrics analysis) on samples consisting of digital images of five worker forewings per colony. These were collected from 394 colonies of Africanized bees from all over Brazil and from colonies of African bees, Apis mellifera scutellata $(\mathrm{n}=14)$, and European bees, A. m. ligustica $(\mathrm{n}=10)$, A. m. mellifera $(\mathrm{n}=15)$, and A. m. carnica $(\mathrm{n}=15)$ from the Ruttner collection in Oberursel, Germany (preserved specimens). Both methods required less than five minutes per sample, giving more than $99 \%$ correct identifications. There was just one misidentification (based on geometric morphometrics analysis) of Africanized bees compared with European subspecies, which would be the principal concern in newly-colonized areas, such as the southern USA. These new techniques are inexpensive, fast and precise.
\end{abstract}

Africanized honey bee / morphometrics / geometric morphometrics analysis / ABIS / Apis mellifera / automatic identification

\section{INTRODUCTION}

After the introduced African honey bee, Apis mellifera scutellata Lepeletier, escaped from a university apiary in Brazil in 1957, it crossed with the previously-established European bee races (Kerr, 1967); the resultant polyhybrid, named the 'Africanized bee' (Gonçalves, 1974), spread throughout most of South and Central America by 1987. Subsequently, it invaded Mexico and reached the USA in 1991 (Rinderer et al., 1993). Though the behavior of Africanized bees is considerably different from that of other European Apis

Corresponding author: T.M. Francoy, tfrancoy@rge.fmrp.usp.br

* Manuscript editor: Stefan Fuchs mellifera races, they are quite similar in appearance; often beekeepers and the public only became aware of their presence after stinging incidents. Consequently, there has been considerable interest in methods for identifying Africanized honey bees so that proper management decisions can be made.

Various methods have been developed to identify Africanized bees, including analyses of isozymes (Contel et al., 1977; Del Lama et al., 1988), mitochondrial DNA polymorphisms (Hall and Muralidharan, 1989; Smith et al., 1989; Sheppard et al., 1991a, b; Segura, 2000), cuticular hydrocarbons (Francis et al., 1985), and nuclear DNA (Hall, 1988; Clarke et al., 2002; Whitfield et al., 2006). However, these biochemical and molecular methods 
require expensive reagents and laboratory equipment.

Morphometrics has been and continue to be the most widely-used official methodology for identifying Africanized honey bees, because of high practicability and low costs. The first effective procedure, developed in the 1970s, consisted of manually measuring 25 characters of the wings, sternites and legs with an ocular micrometer; these measures were then analyzed with multivariate statistics to make the identifications (Daly and Baling, 1978). This identification method was later improved by incorporation of computerassisted measurements (Daly et al., 1982). A simplification of these procedures resulted in the "Fast Africanized Bee Identification System" (FABIS) for preliminary identification in the field (Rinderer et al., 1986). Whenever colonies are suspected to be Africanized based on FABIS, official identification in the USA is currently made with the USDAID (United States Department of Agriculture identification) method (Rinderer et al., 1993). This method uses 25 morphometric measurements, manually entered into a computer program, of five balsam-mounted parts of each bee (fore- and hindwing, femur-tibia, basitarsus of a hind leg and a sternite); though it has good precision, it requires skilled personnel and several hours of preparation and analysis per 10-bee sample. These limitations and continuing reductions in the costs of molecular biology technology have turned DNA recognition systems into an attractive alternative to morphometrics.

However, recent advances in statistical analysis and image recognition software have made morphometric analysis more precise and practical for identifying species. Schröder et al. (1995) developed a semi-automatic system for bee species recognition, based on characteristics extracted from the forewings; this system was named ABIS (Automatic Bee Identification System). The landmarks of this system were manually-plotted wing-vein junctions; after training the system with at least 30 individuals per group, the identification of individuals was quite fast. Several improvements were subsequently made to the original ABIS system; the new version requires lit- tle user input and has greater precision than the original version (Steinhage et al., 2001). ABIS is a supervised classification method; i.e. the program must be trained with at least 20 specimens of each class (such as species, race, or population). Currently, ABIS is able to automatically identify and mark the landmarks in the digital images of the wings. Another improvement is the use of non-linear discriminant analysis based on kernel functions (Roth and Steinhage, 1999), instead of linear discriminant analysis, for the differentiation of the groups. ABIS was able to discriminate European members of the genera Colletes, Andrena and Bombus (Steinhage et al., 2001) to the species level with a precision of $99.8 \%$, and it correctly identified $94 \%$ of the bees in a comparison of honey bee subspecies (Drauschke et al., 2007; Francoy et al., in press).

Another modern morphometric method that is also very promising for shape studies is geometrics morphometrics based on the description of shape in Cartesian coordinates (Bookstein, 1991). Though they are very useful for reconstructing shapes, since the relative position of landmarks is retained during analysis (Rohlf and Marcus, 1993), the use of these techniques in honey bees has till now been restricted to analysis of fluctuating asymmetry in studies of hybridization (Smith et al., 1997; Schneider et al., 2003). We have found that this technique can be used to identify honey bee subspecies; in a preliminary study, we were able to identify $85 \%$ of the individuals in a comparison of European and Africanized bees (Francoy et al., in press).

Based on these initial studies, we investigated the utility of these two morphometric techniques (ABIS and geometric morphometrics analysis) for distinguishing Africanized honey bees collected from all regions of Brazil from the African and European subspecies that gave origin to this polyhybrid.

\section{MATERIAL AND METHODS}

Worker bees from 394 colonies of Africanized honey bees were collected from 24 different localities from 16 of the 24 states of Brazil (Tab. I). 
Table I. Localities (city and state) and number of Africanized honey bee colonies sampled in Brazil (in 1997). $\mathrm{N}=$ number of colonies sampled.

\begin{tabular}{|c|c|}
\hline Locality & Latitude Longitude $\mathrm{N}$ \\
\hline Belém, PA & $1^{\circ} 26^{\prime} \mathrm{S} \quad 48^{\circ} 29^{\prime} \mathrm{W} 20$ \\
\hline São Luis, MA & $2^{\circ} 31^{\prime} \mathrm{S} \quad 44^{\circ} 18^{\prime} \mathrm{W} 20$ \\
\hline Fortaleza, CE & $3^{\circ} 46^{\prime} \mathrm{S} \quad 38^{\circ} 35^{\prime} \mathrm{W} 40$ \\
\hline Baraúna, RN & $5^{\circ} 05^{\prime} \mathrm{S} \quad 37^{\circ} 36^{\prime} \mathrm{W} 6$ \\
\hline Serra do Mel, RN & $5^{\circ} 10^{\prime} \mathrm{S} 37^{\circ} 02^{\prime} \mathrm{W} \quad 8$ \\
\hline Mossoró, RN & $5^{\circ} 11^{\prime} \mathrm{S} 37^{\circ} 20^{\prime} \mathrm{W} 5$ \\
\hline Severiano Melo, RN & $5^{\circ} 46^{\prime} \mathrm{S} \quad 37^{\circ} 57^{\prime} \mathrm{W} \quad 5$ \\
\hline Catolé do Rocha, PB & $6^{\circ} 20^{\prime} \mathrm{S} 37^{\circ} 45^{\prime} \mathrm{W} \quad 3$ \\
\hline Picos, PI & $7^{\circ} 05^{\prime} \mathrm{S} \quad 41^{\circ} 46^{\prime} \mathrm{W} 25$ \\
\hline Crato, CE & $7^{\circ} 14^{\prime} \mathrm{S} 39^{\circ} 25^{\prime} \mathrm{W} 22$ \\
\hline Araripina, $\mathrm{PE}$ & $7^{\circ} 33^{\prime} \mathrm{S} \quad 40^{\circ} 34^{\prime} \mathrm{W} 20$ \\
\hline Aracaju, SE & $10^{\circ} 54^{\prime} \mathrm{S} 37^{\circ} 03^{\prime} \mathrm{W} 20$ \\
\hline Tucano, BA & $10^{\circ} 58^{\prime} \mathrm{S} 38^{\circ} 47^{\prime} \mathrm{W} 20$ \\
\hline Salvador, BA & $12^{\circ} 58^{\prime} \mathrm{S} 38^{\circ} 30^{\prime} \mathrm{W} 13$ \\
\hline Aquidauana, MS & $20^{\circ} 28^{\prime} \mathrm{S} 55^{\circ} 47^{\prime} \mathrm{W} 19$ \\
\hline Ribeirão Preto, SP & $21^{\circ} 10^{\prime} \mathrm{S} 47^{\circ} 51^{\prime} \mathrm{W} 18$ \\
\hline São João da Boa Vista, SP & $21^{\circ} 59^{\prime} \mathrm{S} 46^{\circ} 47^{\prime} \mathrm{W} 12$ \\
\hline Rio de Janeiro, RJ & $22^{\circ} 54^{\prime} \mathrm{S} 43^{\circ} 12^{\prime} \mathrm{W} 20$ \\
\hline Maringá, PR & $23^{\circ} 24^{\prime} \mathrm{S} 51^{\circ} 55^{\prime} \mathrm{W} 10$ \\
\hline Curitiba, PR & $25^{\circ} 25^{\prime} \mathrm{S} 49^{\circ} 17^{\prime} \mathrm{W} 20$ \\
\hline Florianópolis, SC & $27^{\circ} 35^{\prime} \mathrm{S} \quad 48^{\circ} 32^{\prime} \mathrm{W} 19$ \\
\hline Santa Maria, RS & $29^{\circ} 41^{\prime} \mathrm{S} 53^{\circ} 49^{\prime} \mathrm{W} 20$ \\
\hline Alegrete, RS & $29^{\circ} 47^{\prime} \mathrm{S} 55^{\circ} 47^{\prime} \mathrm{W} 14$ \\
\hline Porto Alegre, RS & $30^{\circ} 02^{\prime} \mathrm{S} 51^{\circ} 13^{\prime} \mathrm{W} 15$ \\
\hline
\end{tabular}

The Ribeirão Preto sample was collected in 2002.

Additionally, wings of workers from 14 colonies of A. m. scutellata, 10 colonies of A. m. ligustica Spinola,15 colonies of A. m. mellifera L. and 15 colonies of A. m. carnica Pollmann were obtained from the Morphometric Bee Data Bank in Oberursel, Germany (the Ruttner collection) and used as parameters of pure subspecies in the comparisons. These four subspecies were selected because they were the main subspecies introduced into Brazil (Francoy et al., in press).

The right forewings of approximately five bees per colony were mounted between microscope slides and photographed with a digital camera attached to a stereomicroscope. The wings of the subspecies from the Ruttner collection were also photographed with the same equipment and to the same scale.

We analyzed the bee wings individually with ABIS (Steinhage et al., 2001). Initially, ABIS performs a detailed analysis of the venation of the wings. The geometry and structure of this venation network is used by this software as fingerprints for bee species (Steinhage et al., 2001). The measures made by ABIS are described in Drauschke et al. (2007). In a second step, a statistical classification is made using nonlinear kernel discriminant analysis (Roth and Steinhage, 1999).

For the geometric morphometrics analysis, 19 homologous landmarks were manually plotted at the wing vein intersections (Fig. 1) using the software tpsDig, version 2.04 (Rohlf, 2005); these images were then Procrustes aligned (Bookstein, 1991). After alignment of the Cartesian coordinates of the wings, the mean configuration of the bees from a colony was used as a comparative parameter and the identifications were made at the colony level. A forward stepwise analysis (tolerance 0.01; $\mathrm{F}$ to enter 1.00) was carried out to determine classification functions, followed by a canonical analysis and then a cross validation test to check the accuracy of the equations in identifying the colonies.

\section{RESULTS}

\subsection{ABIS}

We ran a cross validation test 30 times for all the groups; each time $10 \%$ of the individuals (randomly selected) were used as unknowns (Tab. II). During this test, the nonlinear Kernel Discriminant Analysis (KDA) of ABIS correctly identified $98.05 \%$ of the individuals from all the groups. If we take into consideration just the Africanized bee specimens, among 5280 identifications, only four Africanized bees were incorrectly identified as A. m. scutellata $(0.08 \%)$. The most common errors in the identifications made with ABIS were for the subspecies $A$. m. ligustica and $A$. $m$. carnica. ABIS was able to correctly identify $80 \%$ of the A. m. ligustica and $85 \%$ of the A. m. carnica samples.

\subsection{Geometric morphometrics analysis}

Among the 38 Cartesian coordinates, 31 were used in the classification model of the five groups. Using multivariate analysis of variance (MANOVA), we found significant differences between the groups (Wilk's $\lambda=$ 0.03623; $P<0.0001)$. The Mahalanobis 


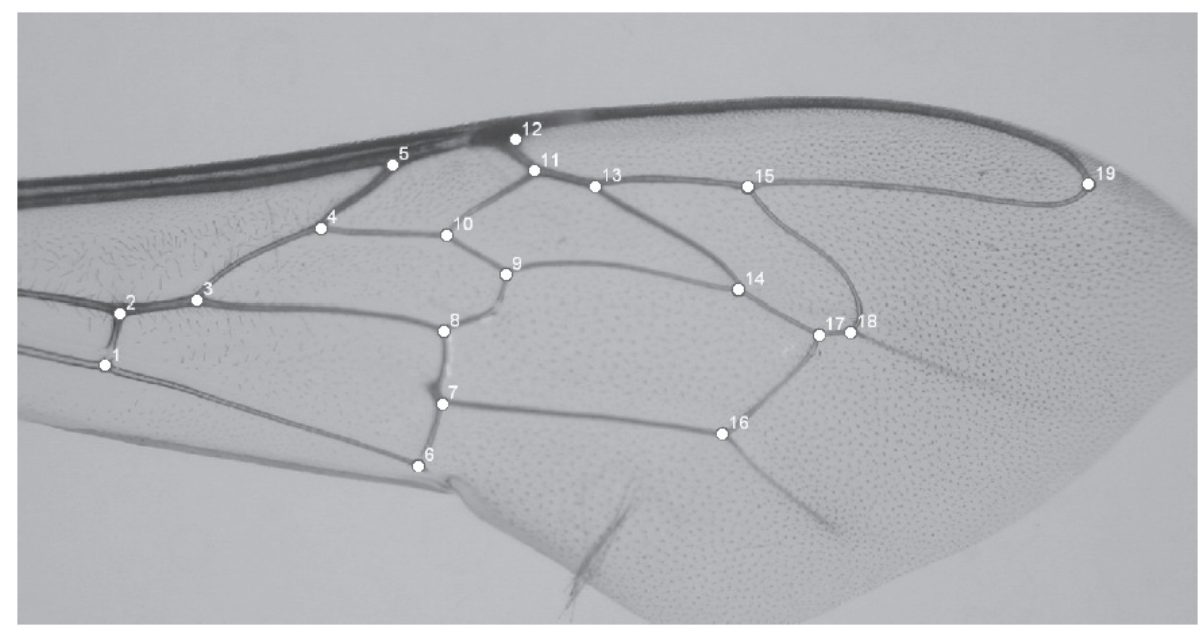

Figure 1. Forewing of Africanized honey bee worker with 19 landmarks plotted in the vein junctions.

square distances between the centroids were also significant (linear discriminant analysis, $P<0.00001)$.

Cross validation tests based on linear discriminant functions correctly identified $97.8 \%$ of the colonies (Tab. III). The mean configuration of the Cartesian coordinates and the discriminant functions for each group are presented in additional online material (Appendix I and II, respectively). Among the Africanized bee samples, $99.2 \%$ of the colonies were correctly identified; $0.5 \%$ of the Africanized colonies $(\mathrm{n}=2)$ were identified as being $A$. $m$. scutellata and just one was wrongly identified as A. m. ligustica. The most common error was misidentification of the A. $m$. scutellata samples: $50 \%$ of the A. m. scutellata colony samples were incorrectly identified as Africanized honey bees.

\section{DISCUSSION}

Though molecular methods work well for identifying Africanized bees (Hall, 1988; Hall and Muralidharan, 1989; Smith et al., 1989; Sheppard et al., 1991a; Segura, 2000; Clarke et al., 2002; Whitfield et al., 2006), they are expensive, require specially-trained personnel and are time consuming. Morphometric identification techniques, which have improved

Table II. Identifications of Apis mellifera subspecies based on ABIS (Steinhage et al., 2001) morphometric analysis of forewings. Identifications were made of each bee. There were five bees per colony sample. The first column indicates the expected classifications (based on previously-determined sample identity); $\mathrm{N}=$ the number of colony samples; the numbers under the following columns show the observed classifications.

Identification based on ABIS (\%)

\begin{tabular}{lrrrrrr}
\hline $\begin{array}{l}\text { Expected } \\
\text { classification }\end{array}$ & $\mathrm{N}$ & AHB & A. m. ligustica & A. m. scutellata & A. m. mellifera & A. m. carnica \\
\hline & & & & & & \\
AHB & 394 & 99.92 & 0.00 & 0.08 & 0.00 & 0.00 \\
A. m. ligustica & 10 & 1.25 & 80.00 & 2.50 & 0.00 & 16.25 \\
A. m. scutellata & 14 & 3.85 & 0.26 & 94.10 & 1.79 & 0.00 \\
A. m. mellifera & 15 & 0.00 & 1.67 & 2.50 & 95.00 & 0.83 \\
A. m. carnica & 15 & 2.08 & 11.25 & 0.83 & 0.00 & 85.83 \\
\hline
\end{tabular}

AHB, Africanized honey bee. 
Table III. Identification of Apis mellifera colony samples based on geometric morphometrics analysis of five forewings per colony. The first column indicates the known classifications (previously-determined sample identity), $\mathrm{N}=$ number of colonies; the numbers under the following columns show the classifications based on the morphometric analysis.

Identification based on geometric morphometrics analysis (\%)

\begin{tabular}{lllllll}
\hline $\begin{array}{l}\text { Known } \\
\text { classification }\end{array}$ & $\mathrm{N}$ & A.m. carnica & A. m. ligustica & A. m. mellifera & A. m. scutellata & AHB \\
\hline A. m. carnica & 15 & 93 & 7 & 0 & 0 & 0 \\
A. m. ligustica & 10 & 0 & 100 & 0 & 0 & 0 \\
A. m. mellifera & 15 & 0 & 0 & 100 & 0 & 0 \\
A. m. scutellata & 14 & 0 & 0 & 0 & 50 & 50 \\
AHB & 394 & 0 & 0.3 & 0 & 0.5 & 99.2 \\
\hline
\end{tabular}

AHB, Africanized honey bee.

considerably due to new computational techniques, are currently more practical since they require little technical knowledge or specialized equipment.

With the evolution of computational morphometrics identification systems, it is now possible to identify species of various groups of insects using only wing features (Steinhage et al., 2001; Tofilski, 2004; Francoy et al., 2006; Steinhage et al., 2007; Drauschke et al., 2007; Mendes et al., 2007). Here, we have extended this strategy to a large sample of Africanized honey bees. There were few misidentifications with these two methods; just one of the Africanized bee colonies was incorrectly identified (based on geometric morphometrics analysis) as being bees of European subspecies, which normally would be the main concern for such analyses. This high level of precision, along with the rapidity of the technique, and the relatively low cost of the necessary infrastructure (stereomicroscope, digital camera, computer and software), makes these two methods attractive alternatives for routine identifications. Once ABIS is trained with a data set of bees, the identification of each individual takes no longer than two minutes; the same procedure with geometric morphometrics analysis of colonies takes about five minutes. All the softwares that we used for geometric morphometrics analysis are freely available on the internet at http://life.bio.sunysb.edu/morph/. Though it is not available to the general public, the ABIS software can be used in cooperation with the
Institute of Informatics III at the University of Bonn.

Very few samples of Africanized honey bees were incorrectly classified as pure A. m. scutellata; which is no longer found in the Neotropics. Rinderer et al. (1990) also concluded that the AHB has a morphometric profile different from that of $A$. m. scutellata. Here we add that it is also different from the three European subspecies that had been previously introduced to Brazil.

Currently, classic morphometric identification methodologies for Africanized honey bees, such as USDA-AID (Rinderer et al., 1993), are time consuming. Both of these new methodologies, ABIS and geometric morphometrics analysis, proved to be very efficient and fast for the identification of Africanized honey bees, and thus would be useful for such identifications in new or recently-colonized areas and for border control programs.

\section{ACKNOWLEDGEMENTS}

The authors thank Dr. Zila Luz Paulino Simões (director of the FINEP project - Study of the degree of hybridization of Africanized honey bees and their southern distribution limits) for providing most of the Africanized bee samples. Dr. Stefan Fuchs allowed us to analyze digital images of the African and European bee species. We also thank two anonymous reviewers for helpful comments. FAPESP, CAPES and CNPq provided funding and scholarships. 
Deux procédés rapides et efficaces pour identifier les abeilles africanisées à l'aide de la morphométrie de l'aile.

\section{Apis mellifera / abeille africanisée / morphomé- trie / ABIS / identification automatique}

\begin{abstract}
Zusammenfassung - Zwei schnelle und effiziente Verfahren zur Identifikation Afrikanisierter Honigbienen anhand der Flügelmorphometrie. Die Afrikanisierten Honigbienen sind unter den verschiedenen Unterarten und Rassengruppen der Honigbiene (Apis mellifera L.) in den Neotropen und den Nachbarregionen am meisten respektiert und gefürchtet, insbesondere da sie in neue Gebiete einwandern. Die Identifizierung der Afrikanisierten Bienen ist in diesen Regionen für die Bewirtschaftung der Bienenvölker daher unverzichtbar. Sie ermöglicht die Bestimmung ihres Verbreitungsgebiets und ihrer Ausbreitungsgeschwindigkeit, dies ist sowohl für die Imker als auch für die damit befassten Regierungseinrichtungen von Bedeutung.
\end{abstract}

Wir benutzten zwei kürzlich entwickelte morphometrische Techniken (ABIS - Automatic Bee Identification System und die Geometrische Morphometrische Analyse), um Proben aus jeweils fünf rechten Vorderflügeln pro Volk zu analysieren (Tab. I). Beide dieser Methoden benötigten in einem Vergleich von 394 über ganz Brasilien verteilten Völkern weniger als 5 Minuten pro Volk und erreichten eine mehr als $99 \%$ korrekte Identifizierung. Diese ergaben 14 Völker von A. m. scutellata, 10 Völker von A. m. ligustica, 15 Völker von A. m. mellifera und 15 Völker von A. m. carnica (Tab. II und III). Mit ABIS können einzelne Bienen bestimmt werden, während die Geometrische Morphometrische Analyse eine auf jeweils 5 Flügeln beruhende Identifikationen auf Kolonieebene durchführt. Die meisten der Fehleinordnungen fanden zwischen Afrikanisierten und Afrikanischen Bienen sowie zwischen den europäischen Unterarten statt. Nur eines der Afrikanisierten Bienenvölker wurde irrtümlich als eine europäische Unterart eingeordnet, dies ist die Fehlerart die insbesondere innerhalb von neubesiedelten Gebieten wie den Südstaaten der USA von Bedeutung wäre. Die erreichten Fortschritte in Computertechnologie, statistischen Analysen und Bilderkennungssoftware sowie die verbesserten Informationen über die relevanten Messgrößenbereiche und die höhere Genauigkeit und größere Geschwindigkeit der Messungen selbst machen es nun möglich, Afrikanisierte Bienen ausschließlich anhand von Digitalaufnahmen der Vorderflügel in Minutenschnelle zu identifizieren.

Afrikanisierte Honigbienen / Morphometrie / Geometrische Morphometrische Analyse / ABIS / Apis mellifera / automatische Identifikation

\section{REFERENCES}

Bookstein F.L. (1991) Morphometric Tools for Landmark Data. Geometry and Biology, Cambridge University Press, New York.

Clarke K.E., Rinderer T.E., Franck P., Quezada-Euan J.G., Oldroyd B.P. (2002) The Africanization of honeybees (Apis mellifera L.) of the Yucatan: A study of a massive hybridization event across time, Evolution 56, 1462-1474.

Contel E.P.B., Mestriner M.A., Martins E. (1977) Genetic-Control and Developmental Expression of Malate-Dehydrogenase in Apis mellifera, Biochem. Genet. 15, 859-876.

Daly H.V., Balling S.S. (1978) Identification of Africanized honeybees in the Western Hemisphere by discriminant analysis, J. Kans. Entomol. Soc. $51,857-869$.

Daly H.V., Hoelmer K., Norman P., Allen T. (1982) Computer assisted measurement and identification of honey bees, Ann. Entomol. Soc. Am. 75, 591594.

Del Lama M.A., Figueiredo R.A., Soares A.E.E., Del Lama S.N. (1988) Hexokinase polymorphism in Apis mellifera and its use for Africanized honeybee identification, Rev. Bras. Genet. 11, 287-297.

Drauschke M., Steinhage V., Pogoda A., Müller S., Francoy T.M., Wittmann D. (2007) Reliable Biometrical Analysis in Biodiversity Information Systems, in: Proc. 7th Int. Workshop on Pattern Recognition in Information Systems, Funchal, Portugal, pp. 25-36.

Francis B.R., Blanton W.E., Nunamaker R.A. (1985) Extractable surface hydrocarbons of workers and drones of the genus Apis, J. Apic. Res. 24, 13-26.

Francoy T.M., Prado P.P.R., Gonçalves L.S., Costa L.D., De Jong D. (2006) Morphometric differences in a single wing cell can discriminate Apis mellifera racial types, Apidologie 37, 91-97.

Francoy T.M., Wittmann D., Steinhage V., Drauschke M., Müller S., Cunha D.R., Nascimento A.M., Figueiredo V.L.C., Simões Z.L.P., De Jong D., Arias M.C., Gonçalves L.S., Morphometric and genetic changes in a population of Apis mellifera after 34 years of Africanization, Genet. Mol. Res. (in press).

Gonçalves L.S. (1974) The introduction of the African Bees (Apis mellifera adansonii) into Brazil and some comments on their spread in South America, Am. Bee J. 114, 414-419.

Hall H.G. (1988) Distinguishing African and European honeybees using nuclear DNA restriction fragment polymorphisms, Fla. Entomol. 71, 294-299.

Hall H.G., Muralidharan K. (1989) Evidence from mitochondrial DNA that African honey bee spread as continuous maternal lineages, Nature 339, 211213.

Kerr W.E. (1967) The history of the introduction of Africanized bees to Brazil, S. Afr. Bee J. 39, 3-5. 
Mendes M.F.M., Francoy T.M., Nunes-Silva P., Menezes C., Imperatriz-Fonseca V.L. (2007) Intra-populational variability of Nannotrigona testaceicornis Lepeletier 1836 (Hymenoptera, Meliponini) using relative warp analysis, Biosci. J. 23, 147-152.

Rinderer T.E., Sylvester H.A., Brown M.A., Villa J.D., Pesante D., Collins A.M. (1986) Field and simplified techniques for identifying Africanized and European honey bees, Apidologie 17, 33-48.

Rinderer T.E., Daly H.V., Sylvester H.A., Collins A.M., Buco S.M., Hellmich R.L., Danka R.G. (1990) Morphometric Differences among Africanized and European Honey-Bees and Their F1 Hybrids (Hymenoptera, Apidae), Ann. Entomol. Soc. Am. 83, 346-351.

Rinderer T.E., Buco S.M., Rubink W.L., Daly H.V., Stelszer J.A., Rigio R.M. (1993) Morphometric identification of Africanized and European honey bees using large reference populations, Apidologie 24, 569-585.

Rohlf F.J., Marcus L.F. (1993) A Revolution in Morphometrics, Trends Ecol. Evol. 8, 129-132.

Rohlf F.J. (2005) tpsDig, version 2.04, Department of Ecology and Evolution, State University of New York, Stony Brook.

Roth V., Steinhage V. (1999) Nonlinear Discriminant Analysis Using Kernel Functions, In Technical Report, Department of Computer Science III. Universität Bonn, Bonn.

Schneider S.S., Leamy L.J., Lewis L.A., De GrandiHoffman G. (2003) The influence of hybridization between African and European honeybees, Apis mellifera, on asymmetries in wing size and shape, Evolution 57, 2350-2364.

Schröder S., Drescher W., Steinhage V., Kastenholz B. (1995) An Automated Method for the Identification of Bee Species (Hymenoptera: Apoidea), In Proc. Int. Symp. on Conserving
Europe's Bees, Int. Bee Research Assoc. \& Linnean Society, pp. 6-7.

Segura J.A.L. (2000) Highly polymorphic DNA markers in an Africanized honey bee population in Costa Rica, Genet. Mol. Biol. 23, 317-322.

Sheppard W.S., Rinderer T.E., Mazzoli J., Stelzer J.A., Shimanuki H. (1991a) Gene flow between African- and European-derived honey bee populations in Argentina, Nature 321, 674-679.

Sheppard W.S., Soares A.E.E., De Jong D., Shimanuki H. (1991b) Hybrid status of honey bee populations near the historic origin of Africanization in Brazil, Apidologie 22, 643-652.

Smith D.R., Taylor O., Brow W.M. (1989) Neotropical Africanized honey bees have African mitochondrial DNA, Nature 339, 213-215.

Smith D.R., Crespi B.J., Bookstein F.L. (1997) Fluctuating asymmetry in the honey bee, Apis mellifera: effects of ploidy and hybridization, J. Evol. Biol. 10, 551-574.

Steinhage V., Arbuckle T., Schröder S., Cremers A.B., Wittmann D. (2001). ABIS: Automated Identification of Bee Species. BIOLOG Workshop, German Programme on Biodiversity and Global Change, Status Report, pp. 194-195.

Steinhage V., Schröder S., Lampe K.H., Cremers A.B. (2007) Automated extraction and analysis of morphological features for species identification, in: N. MacLeod (Ed.), Automated Object Identification in Systematics: Theory, Approaches, and Applications, pp. 115-129.

Tofilski A. (2004) DrawWing, a program for numerical description of insect wings, J. Insect Sci. 4, 17-22.

Whitfield C.W., Behura S.K., Berlocher S.H., Clark A.G., Johnston J.S., Sheppard W.S., Smith D.R., Suarez A.V., Weaver D., Tsutsui N.D. (2006) Thrice out of Africa: Ancient and recent expansions of the honey bee, Apis mellifera, Science $314,642-645$. 
Apidologie 39 (2008) 488-494

\section{Online Material}


Appendix I. Mean values of the Cartesian coordinates according to the respective group and the mean configuration of all the colonies.

\begin{tabular}{|c|c|c|c|c|c|c|}
\hline & $\overline{\mathrm{AHB}}$ & A. m. scutellata & A. m. mellifera & A. m. ligustica & A. m. carnica & all \\
\hline $1 \mathrm{x}$ & -0.3448 & -0.3487 & -0.3467 & -0.3469 & -0.3476 & -0.3451 \\
\hline $1 \mathrm{y}$ & -0.1296 & -0.1313 & -0.1303 & -0.1317 & -0.1305 & -0.1297 \\
\hline $2 x$ & -0.3411 & -0.3441 & -0.3446 & -0.3430 & -0.3445 & -0.3414 \\
\hline $2 y$ & -0.0833 & -0.0837 & -0.0839 & -0.0834 & -0.0820 & -0.0833 \\
\hline $3 x$ & -0.2881 & -0.2874 & -0.2930 & -0.2943 & -0.2933 & -0.2885 \\
\hline $3 y$ & -0.0639 & -0.0637 & -0.0652 & -0.0663 & -0.0646 & -0.0640 \\
\hline $4 x$ & -0.1823 & -0.1786 & -0.1811 & -0.1829 & -0.1835 & -0.1822 \\
\hline $4 y$ & 0.0179 & 0.0190 & 0.0180 & 0.0212 & 0.0207 & 0.0181 \\
\hline $5 x$ & -0.1327 & -0.1321 & -0.1364 & -0.1378 & -0.1386 & -0.1332 \\
\hline $5 y$ & 0.0776 & 0.0768 & 0.0748 & 0.0786 & 0.0782 & 0.0775 \\
\hline $6 x$ & -0.0696 & -0.0710 & -0.0673 & -0.0623 & -0.0625 & -0.0692 \\
\hline $6 y$ & -0.1713 & -0.1719 & -0.1697 & -0.1742 & -0.1735 & -0.1714 \\
\hline $7 \mathrm{x}$ & -0.0559 & -0.0564 & -0.0520 & -0.0507 & -0.0521 & -0.0555 \\
\hline $7 y$ & -0.1168 & -0.1168 & -0.1174 & -0.1193 & -0.1176 & -0.1169 \\
\hline $8 x$ & -0.0611 & -0.0599 & -0.0595 & -0.0555 & -0.0559 & -0.0607 \\
\hline $8 y$ & -0.0541 & -0.0549 & -0.0529 & -0.0533 & -0.0535 & -0.0541 \\
\hline $9 \mathrm{x}$ & -0.0134 & -0.0119 & -0.0110 & -0.0020 & -0.0035 & -0.0127 \\
\hline $9 y$ & 0.0065 & 0.0063 & 0.0098 & 0.0082 & 0.0083 & 0.0067 \\
\hline $10 \mathrm{x}$ & -0.0636 & -0.0620 & -0.0614 & -0.0603 & -0.0571 & -0.0632 \\
\hline $10 y$ & 0.0278 & 0.0281 & 0.0280 & 0.0323 & 0.0316 & 0.0280 \\
\hline $11 x$ & -0.0070 & -0.0051 & -0.0071 & -0.0066 & -0.0068 & -0.0069 \\
\hline $11 y$ & 0.0917 & 0.0922 & 0.0901 & 0.0942 & 0.0930 & 0.0918 \\
\hline $12 x$ & -0.0298 & -0.0289 & -0.0294 & -0.0292 & -0.0305 & -0.0298 \\
\hline $12 y$ & 0.1141 & 0.1146 & 0.1136 & 0.1177 & 0.1163 & 0.1142 \\
\hline $13 x$ & 0.0502 & 0.0502 & 0.0523 & 0.0498 & 0.0508 & 0.0503 \\
\hline $13 y$ & 0.0895 & 0.0894 & 0.0872 & 0.0926 & 0.0913 & 0.0895 \\
\hline $14 \mathrm{x}$ & 0.1818 & 0.1795 & 0.1834 & 0.1765 & 0.1770 & 0.1815 \\
\hline $14 y$ & 0.0239 & 0.0248 & 0.0245 & 0.0236 & 0.0223 & 0.0239 \\
\hline $15 \mathrm{x}$ & 0.1730 & 0.1739 & 0.1741 & 0.1593 & 0.1561 & 0.1722 \\
\hline $15 y$ & 0.1085 & 0.1079 & 0.1067 & 0.1072 & 0.1044 & 0.1083 \\
\hline $16 x$ & 0.1876 & 0.1887 & 0.1848 & 0.1904 & 0.1936 & 0.1878 \\
\hline $16 y$ & -0.1030 & -0.1022 & -0.0981 & -0.1041 & -0.1028 & -0.1028 \\
\hline $17 x$ & 0.2553 & 0.2556 & 0.2516 & 0.2556 & 0.2594 & 0.2553 \\
\hline $17 y$ & -0.0018 & -0.0014 & 0.0015 & -0.0019 & -0.0025 & -0.0017 \\
\hline $18 \mathrm{x}$ & 0.2861 & 0.2861 & 0.2889 & 0.2859 & 0.2874 & 0.2862 \\
\hline $18 \mathrm{y}$ & 0.0061 & 0.0076 & 0.0102 & 0.0077 & 0.0065 & 0.0063 \\
\hline $19 x$ & 0.4554 & 0.4522 & 0.4545 & 0.4542 & 0.4517 & 0.4551 \\
\hline $19 y$ & 0.1603 & 0.1592 & 0.1530 & 0.1509 & 0.1543 & 0.1596 \\
\hline
\end{tabular}


Appendix II. Classification functions for the discrimination of the Africanized honey bees and the subspecies that were compared with the Africanized bees. The functions were calculated based on the Cartesian coordinates (CC) of the vein junctions.

\begin{tabular}{|c|c|c|c|c|c|}
\hline & A. m. carnica & A. m. ligustica & A. m. mellifera & A. m. scutellata & $\overline{\mathrm{AHB}}$ \\
\hline $9 \mathrm{X}$ & -165025 & -164154 & -162947 & -166132 & -165481 \\
\hline $19 \mathrm{Y}$ & 1189204 & 1185782 & 1182402 & 1188857 & 1186436 \\
\hline $15 \mathrm{X}$ & -2448 & -1661 & 420 & -1507 & -584 \\
\hline $18 \mathrm{Y}$ & 808265 & 807988 & 803183 & 807527 & 804127 \\
\hline $9 \mathrm{Y}$ & 147610 & 146353 & 149461 & 146272 & 146419 \\
\hline $10 \mathrm{Y}$ & 484664 & 483617 & 478210 & 481943 & 481561 \\
\hline $15 \mathrm{Y}$ & 512855 & 513191 & 512930 & 514914 & 514174 \\
\hline $13 Y$ & 574236 & 572514 & 565296 & 568592 & 568143 \\
\hline $14 \mathrm{Y}$ & 447740 & 447914 & 446987 & 452087 & 450421 \\
\hline $14 \mathrm{X}$ & 136993 & 137985 & 139978 & 138453 & 139227 \\
\hline $11 \mathrm{Y}$ & 337904 & 335977 & 337426 & 340595 & 338965 \\
\hline $17 \mathrm{X}$ & 470162 & 469789 & 469404 & 469596 & 469937 \\
\hline $7 Y$ & -167548 & -169053 & -170912 & -168476 & -169057 \\
\hline $18 \mathrm{X}$ & 281223 & 281305 & 283388 & 280467 & 281042 \\
\hline $13 \mathrm{X}$ & -165991 & -165292 & -163850 & -167050 & -165661 \\
\hline $4 \mathrm{X}$ & -531378 & -530706 & -529039 & -531691 & -531389 \\
\hline $5 \mathrm{X}$ & -372768 & -371736 & -369818 & -371517 & -370564 \\
\hline $6 \mathrm{X}$ & 158357 & 157582 & 156126 & 156548 & 156419 \\
\hline $7 \mathrm{X}$ & -155216 & -154189 & -152244 & -154433 & -154218 \\
\hline $10 \mathrm{X}$ & -237738 & -237645 & -236994 & -238598 & -237818 \\
\hline $12 \mathrm{X}$ & -263065 & -261729 & -259317 & -262616 & -261064 \\
\hline 19X & 349587 & 350525 & 351820 & 349482 & 350915 \\
\hline $16 \mathrm{Y}$ & 415144 & 412713 & 412288 & 414201 & 412724 \\
\hline $17 Y$ & 490425 & 486815 & 486262 & 487060 & 486571 \\
\hline $12 \mathrm{Y}$ & 258842 & 258912 & 259112 & 258139 & 257599 \\
\hline $1 X$ & -462812 & -463048 & -461941 & -463278 & -462985 \\
\hline $1 \mathrm{Y}$ & -452792 & -452134 & -450705 & -453884 & -452113 \\
\hline $3 Y$ & -820759 & -820463 & -817061 & -820868 & -819227 \\
\hline $2 \mathrm{X}$ & -729386 & -728650 & -727609 & -729386 & -728715 \\
\hline $11 \mathrm{X}$ & -266281 & -265910 & -264512 & -265844 & -265387 \\
\hline $5 Y$ & 282716 & 281837 & 281725 & 281604 & 282362 \\
\hline Constant & -726214 & -725814 & -724850 & -726443 & -726240 \\
\hline
\end{tabular}

